Afr. J. Trad. CAM (2006) 3 (3): 1 - 9

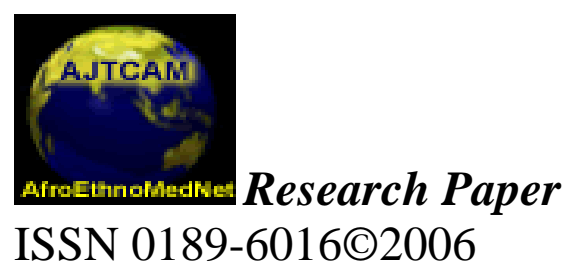

Afr. J. Traditional, Complementary and Alternative Medicines www.africanethnomedicines.net

\title{
POTENTIAL PROTECTIVE EFFECT OF SOME PLANT EXTRACTS AGAINST CARBON TETRACHLORIDE - INDUCED HEPATOTOXICITY
}

\section{Attia H Atta*, Soad M. Nasr" and Samar M. Mouneir}

Pharmacology Department, Faculty of Veterinary Medicine, Cairo University, Giza 12211 and " Parasitology and Animal Diseases Department, National

Research Center, Giza, Egypt Abstract

E-mail: attia_atta@yahoo.com ,Fax 025695676

\begin{abstract}
Plantago major seeds, Diplotaxis acris and Schouiwa thebaica methanol extracts were evaluated for their potential hepatoprotective effects against carbon tetrachloride induced hepatic damage model. Preliminary phytochemical studies were carried out to elucidate their components. Oral administration of the methanol extract (1000 $\mathrm{mg} \mathrm{kg}^{-1}$ ) of Plantago major seeds, Diplotaxis acris and Schouiwa thebaica significantly $(\mathrm{P}<0.05)$ attenuated the $\mathrm{CCl}_{4}$-induced hepatotoxicity. This was indicated by the tendency of serum enzyme activities to return toward the normal values. Moreover the histopathological changes of liver tissues induced by $\mathrm{CCl}_{4}$ were moderate to mild in methanol extractpretreated rats. No toxic symptoms were reported in rats receiving methanol extract at doses up to $2.5 \mathrm{~g} \mathrm{~kg}^{-1}$. Unsaturated sterols and/or triterpenes, tannins, flavonoids and carbohydrates and/or glycosides were the major active constituents of the tested plants.
\end{abstract}

Key words: hepatoprotective, medicinal plants, Plantago major, Diplotaxis acris, Schouwia thebaica.

\section{Introduction}

Liver is the major site of intensive metabolic activity. Liver dysfunction as a result of toxic chemicals, certain drugs and environmental pollutants has been largely increased in the last few decades. Herbal treatment of many diseases including hepatopathy are increasing in many countries (Venukumar and Latha, 2002, Malaya et al., 2004). Plantago major, a member of family Plantaginaceae, is used in folk medicine as a remedy for inflammations (Jain, 1991 and Zagari, 1992, Ruiz et al., 1996), respiratory affections (Zagari, 1992, Guillen et al., 1997), digestive organs affections and infections (Joshi, et al., 1982, Jain, 1991, Bustos et al., 1996), urogenital system affections (Spring, 1989, Gurib-Fakim et al., 1993) and many other diseases all over the world 
Afr. J. Trad. CAM (2006) 3 (3): 1 - 9

(Samuelsen, 2000). More recently, water soluble compounds isolated from Plantago spp. (especially Plantago major) have been reported to induce an immunostimulating activity on human lymphocyte proliferation (Chiang et al., (2003). Diplotaxis acris belongs to the family Compositae. The members of this family are effective analgesic and antiulcerogenic (Atta and Abo El Sooud, 2004, Alvarez et al., 1999, Atta et al., 2005). Schouwia thebaica has been shown to possess antinociceptive effect (Atta and Abo El Sooud, 2004) and antidiarrhoeal effect (Atta and Mouneir, 2005). People customarily use the extracts of plants known to have gastrointestinal sedative effects without any scientific background. For this reason, we studied the hepatoprotective effect of methanol extract of Plantago major, Diplotaxis acris and Schouwia thebaica commonly grown in Upper Egypt and in the River Nile, Sinai and Delta regions.

\section{Material and methods Plant material}

Plantago major, Diplotaxis acris and Schouwia thebaica were identified by the staff members of the Herbarium of the department of Botany, Faculty of Science, Cairo University. A voucher sample (number A15S, E16, and E20 respectively) was kept in the department of Pharmacology, Faculty of Veterinary Medicine, Cairo University, Egypt. The air-dried plant was moderately pulverized, and stored for further use. The powdered plant (200g) was extracted and percolated in methanol 95\% for 5 to 7 times till complete extraction. The methanol extracts was concentrated under reduced pressure using Rotary Evaporator at temperature not more than $50{ }^{\circ} \mathrm{C}$. The concentrated extract was kept at $-4{ }^{\circ} \mathrm{C}$ until used for phytochemical and pharmacological studies.

\section{Hepatoprotective effect:}

Six groups of 6 rats each were used. First group (normal control) was given $2.5 \mathrm{ml}$ of corn oil / $\mathrm{kg}$ b.wt. daily for 5 days and kept as normal control. Rats of the second group were given the same dose of corn oil, in addition $\mathrm{CCl}_{4}$ ( $50 \%$ in corn oil) was given in a single oral dose of $2.5 \mathrm{ml} \mathrm{kg}^{-1}$ b.wt. two hours after the last dose of the oil. Rats of the third, fourth and fifth groups were pretreated orally with $1000 \mathrm{mg} \mathrm{kg}^{-1}$ b.wt. of Plantago major, Diplotaxis acris and Schouwia thebaica methanol extract suspended in distilled water with few drops of Tween 80. Carbon tetrachloride was given 2 hours of the last dose. Moreover, a $6^{\text {th }}$ group was administered orally $25 \mathrm{mg} \mathrm{kg}^{-1}$ b.wt. silymarin (as a standard drug) daily for 5 days and 2 hours after the last dose, $\mathrm{CCl}_{4}$ was given as before. Animals were handled according to the local rules and regulation of Experimental Animals, Cairo University.

\section{Blood samples}

Blood samples were collected 24 hours after $\mathrm{CCl}_{4}$ administration by puncturing the retro-orbital plexus of veins. Blood samples were allowed 


\section{Afr. J. Trad. CAM (2006) 3 (3): 1 - 9}

to clot and centrifuged to separate clear serum. The activities of aspartate aminotransferases (AST) and Alanine aminotransferase (ALT) (Reitman and Frankel, 1957), gamma glutamyl transferase (GGT) (Szasz, 1969) and the level of glucose (Trinder, 1969), total bilirubin (Malloy and Evelyn, 1937), triglycerides (VanHendle and Zilversmith, 1957), cholesterol (Abell, et al., 1952), total proteins (Henary et al., 1974), albumin (Doumas et al., 1971) were determined.

\section{Pathological studies}

Immediately after sacrifice, liver tissue specimens were collected from all rats and fixed in $10 \%$ formol saline. Paraffin sections of $5 \mu$ thickness were prepared, stained by H \& E and examined microscopically (Harris, 1898).

\section{Acute toxicity study in mice}

The acute toxicity of plant extract was tested as described by Tanira et al., (1996) using three doses (0.4, 1 and $2.5 \mathrm{~g} \mathrm{~kg}^{-1} \mathrm{~b}$. wt., orally). Control rats were kept under the same conditions without any treatments. Observation period extended up to $72 \mathrm{~h}$ post administration. In addition, the general behavior of animals, signs of discomfort, or any nervous manifestations were observed. The large dose was selected to represent the maximum dose in relation to the extract-dry plant yield.

\section{Phytochemical screening}

The extracts were screened for the presence of tannins, saponins, sterols and or triterpenes, alkaloids, anthraquinones, flavonoids, lactones/esters, protein and or amino acids and carbohydrates and or glycosides with thin layer chromatography (TLC) as described by Stahl (1969). Thin layer plates precoated with Silica gel G (Merck, $0.25 \mathrm{~mm}$ thickness) were used. Development was carried out with different solvent systems: ethyl acetatemethanol-water (100: 13.5: $10 \mathrm{v} / \mathrm{v}$ ), ethyl acetate- formic acid -acetic acid water (100:11: 11: $27 \mathrm{v} / \mathrm{v})$, chloroform - methanol - water (64: 50: $10 \mathrm{v} / \mathrm{v})$ benzene: ethyl acetate (86: $14 \mathrm{v} / \mathrm{v})$ and ethyl acetate: methanol: water: acetic acid (65: 15: 15: $10 \mathrm{v} / \mathrm{v} / \mathrm{v} / \mathrm{v})$. After development in the solvents the plates were dried and sprayed with Dragendorrf's, $\mathrm{AlCl}_{3}, \mathrm{Hydroxylamine-ferric} \mathrm{chloride,}$ ninhydrin and antimony trichloride for the detection of alkaloids, flavonoids, lactones/esters, protein/ amino acids and sterols/triterpenes. Detection of anthraquinones, saponins, tannins glycosides/ carbohydrate was carried out using $\mathrm{KOH}$, anisaldehyde-sulphuric acid reagents, ferric chloride and naphthoresorcinol reagents respectively (Wagner et al., 1983). Detection was carried out by visualization in visible light and under UV light $(\lambda 366 \mathrm{~nm})$.

\section{Statistical analysis}

Results are expressed as mean \pm standard deviation (SD). Differences between means in different groups were tested for significance using a one-way 
Afr. J. Trad. CAM (2006) 3 (3): 1- 9

analysis of variance (ANOVA) followed by Duncan's test and P value of 0.05 or less was considered significant.

\section{Results}

$\mathrm{CCl}_{4}$ markedly increased serum aminotransferases (ALT, AST) and GGT activities but exhibited a significant decrease in concentrations of serum glucose and triglycerides. The total bilirubin was slightly elevated. Pretreatment with Plantago major methanol extract significantly decreased the $\mathrm{CCl}_{4}$-induced elevation of serum aminotransferases (ALT, AST) and GGT activities. The levels of serum total bilirubin, triglycerides and albumin were also decreased (Table 1). However total protein was slightly elevated. Similar results were observed by oral administration of Diplotaxis acris $(1000 \mathrm{mg} / \mathrm{kg}$ b.wt.) except that it had no effect on total bilirubin, total protein and albumin. Oral administration of Schouwia thebaica methanol extract significantly decreased the $\mathrm{CCl}_{4}$-induced elevated serum aminotransferases (ALT, AST) and GGT activities and elevated blood triglyceride level. The effect was nearly similar to that of silymarin (Table 1 ).

The liver of rats intoxicated with $\mathrm{CCl}_{4}$ showed severe degenerated and necrobiotic changes (centrolobular) in the hepatocytes (Figure $1 \mathrm{~B}$ ) as compared control non-intoxicated rats (Figure 1A). Livers of rats pretreated with Plantago major, Diplotaxis acris and Schouwia thebaica methanol extracts as well as silymarin showed moderate to mild degenerated and necrobiotic changes (centrolobular) in the hepatocytes. (Figures 1C - D).

Table 1: Effect of methanol extracts of Plantago major seeds, Diplotaxis acris, and Schouwia thebaica methanol extracts at a dose of $1000 \mathrm{mg} \mathrm{kg}^{-1} \mathrm{~b}$ wt. on serum enzymes and biochemical parameters in rats with carbon tetrachloride - induced hepatotoxicity (Means \pm $\mathrm{SD}, \mathrm{n}=6$ ) Means of different letters in the same row are significantly different

\begin{tabular}{|c|c|c|c|c|c|c|}
\hline Groups & $\begin{array}{l}\text { Normal } \\
\text { Control }\end{array}$ & $\begin{array}{c}\text { Carbon } \\
\text { Tetrachloride }\end{array}$ & $\begin{array}{l}\text { Plantago } \\
\text { major seeds }\end{array}$ & $\begin{array}{c}\text { Diplotaxis } \\
\text { acris }\end{array}$ & $\begin{array}{l}\text { Schouwia } \\
\text { thebaica }\end{array}$ & Silymarin \\
\hline ALT (IU/l) & $78.2 \pm 20.1^{\mathrm{a}}$ & $382.2 \pm 78.1^{a}$ & $178.2 \pm 18.8$ & $257.2 \pm 24.5$ & $166.3 \pm 14.9^{c}$ & $177.8 \pm 10.0^{b}$ \\
\hline AST (IU/l) & $206.2 \pm 15.1^{\mathrm{a}}$ & $682.8 \pm 59.4^{\mathrm{c}}$ & $375.0 \pm 56.6$ & $463.2 \pm 66.2$ & $456.2 \pm 88.9^{b}$ & $457.6 \pm 80.8$ \\
\hline GGT (IU/l) & $8.0 \pm 0.7^{c}$ & $20.0 \pm 1.6^{\mathrm{d}}$ & $7.0 \pm 1.0^{\mathrm{bc}}$ & $4.0 \pm 0.7^{b}$ & $6.3 \pm 1.4^{\mathrm{a}}$ & $6.6 \pm 0.6^{\mathrm{bc}}$ \\
\hline $\begin{array}{l}\text { Glucose } \\
\text { (mg/dl) }\end{array}$ & $131.4 \pm 22.1^{c}$ & $93.8 \pm 16.3^{a}$ & $103.4 \pm 10.5$ & $110.5 \pm 9.5^{b}$ & $122.9 \pm 14.2^{\mathrm{a}}$ & $\sqrt{111.3 \pm 3.0^{\mathrm{a}}}$ \\
\hline $\begin{array}{l}\text { T. bilirubin } \\
(\mathrm{mg} / \mathrm{dl})\end{array}$ & $0.36 \pm 0.1^{\mathrm{a} b}$ & $0.41 \pm 0.02^{b}$ & $0.32 \pm 0.04^{\mathrm{a}}$ & $0.40 \pm 0.04^{b}$ & $0.39 \pm 0.04^{b}$ & $0.37 \pm 0.03^{b}$ \\
\hline $\begin{array}{l}\text { Triglycerides } \\
\text { (mg/dl) }\end{array}$ & $134.6 \pm 6.4^{\mathrm{c}}$ & $73.2 \pm 4.8^{b}$ & $59.5 \pm 6.6^{\mathrm{a}}$ & $54.4 \pm 12.5^{b}$ & $76.7 \pm 5.8^{\mathrm{a}}$ & $83.1 \pm 12.8^{\mathrm{b}}$ \\
\hline $\begin{array}{l}\text { Cholesterol } \\
(\mathrm{mg} / \mathrm{dl})\end{array}$ & $82.2 \pm 15.9^{b}$ & $74.4 \pm 9.6^{\mathrm{ab}}$ & $68.1 \pm 9.0^{\mathrm{ab}}$ & $66.5 \pm 12.0^{\mathrm{a}}$ & $64.1 \pm 8.8^{\mathrm{ab}}$ & $73.0 \pm 11.3^{a}$ \\
\hline $\begin{array}{l}\text { Total protein } \\
(\mathrm{g} / \mathrm{dl})\end{array}$ & $6.3 \pm 0.3^{\mathrm{a}}$ & $6.8 \pm 0.6^{\mathrm{ab}}$ & $7.62 \pm 0.21^{\mathrm{c}}$ & $7.21 \pm 0.38^{b}$ & $7.3 \pm 0.4^{\mathrm{bc}}$ & $7.7 .9 \pm 0.60^{\mathrm{d}}$ \\
\hline \begin{tabular}{|l|} 
Albumin \\
$(\mathrm{g} / \mathrm{dl})$
\end{tabular} & $3.9 \pm 0.4^{\mathrm{a}}$ & $4.2 \pm 0.2 \mathrm{a}^{\mathrm{bc}}$ & $3.74 \pm 0.15^{\mathrm{a}}$ & $4.52 \pm 0.72^{\mathrm{ab}}$ & $4.1 \pm 0.4^{\mathrm{bc}}$ & $0.23^{\mathrm{c}}$ \\
\hline
\end{tabular}


Afr. J. Trad. CAM (2006) 3 (3): 1 - 9

\section{Acute toxicity study in mice}

Oral administration of Plantago major seeds, Diplotaxis acris and Schouwia thebaica methanol extracts in doses up $2.5 \mathrm{~g} \mathrm{~kg}^{-1} \mathrm{~b}$. wt. did not cause any major signs of acute toxicity. No deaths were reported up to 72 hours after oral administration.

\section{Phytochemical screening}

Phytochemical screening of Plantago major seeds, Diplotaxis acris and Schouwia thebaica extract revealed the presence of unsaturated sterols and or triterpenes, tannins, flavonoids and carbohydrates and or glycosides. No anthraquinones, lactones/esters, or saponins were found (Table 2)

Table 2: Relative content of active constituents in the methanol extracts of the tested plants

\begin{tabular}{|c|c|c|c|c|c|c|c|c|c|c|}
\hline Test for & 䍖. & 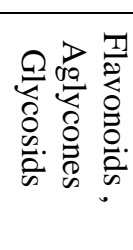 & 疍 & 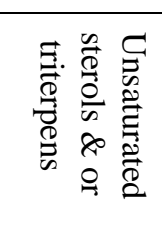 & 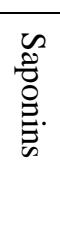 & 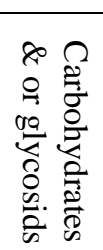 & 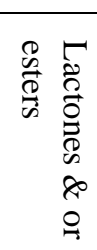 & 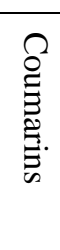 & 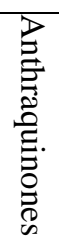 & 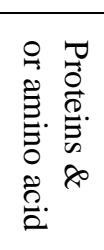 \\
\hline $\begin{array}{l}\text { Plantago } \\
\text { major seeds }\end{array}$ & + & ++ & + & ++ & - & ++ & - & + & - & ++ \\
\hline $\begin{array}{l}\text { Diplotaxis } \\
\text { acris }\end{array}$ & + & +++ & + & +++ & \pm & +++ & \pm & - & - & ++ \\
\hline $\begin{array}{l}\text { Schouwia } \\
\text { thebaica }\end{array}$ & + & ++ & + & +++ & - & ++ & \pm & + & - & ++ \\
\hline
\end{tabular}

\section{Discussion}

In this work we studied the potential hepatoprotective effect of methanol extract of Plantago major seeds, Diplotaxis acris and Schouwia thebaica using the CCl4 model, the most widely used and well described technique for induction of hepatotoxicity (Recknagel et al., 1989).

Carbon tetrachloride administration to experimental animals induced acute pathological changes in the liver. This finding correlates with the marked increase in serum aminotransferases (ALT, AST) and GGT activities. The activity of these enzymes was significantly lower in rats pre-treated with either silymarin or Plantago major seeds, Diplotaxis acris and Schouwia thebaica. Moreover it has been shown that reductive dehalogenation of $\mathrm{CCl}_{4}$ catalyzed by CYP 450 in the liver cell endoplasmic reticulum leads to generation of an unstable highly reactive complex $\mathrm{CCl} \cdot{ }_{3}$ or trichloroperoxyl radical $\left(\mathrm{CCl}_{3} \mathrm{O}_{3}\right)$. These radicals attack microsomal lipids and proteins causing lipid peroxidation, disturbance in Calcium $\left(\mathrm{Ca}^{2+}\right)$ homeostasis and finally cell death (Recknagel, et al., 1989, Wei, 1998). 
Afr. J. Trad. CAM (2006) 3 (3): 1 - 9
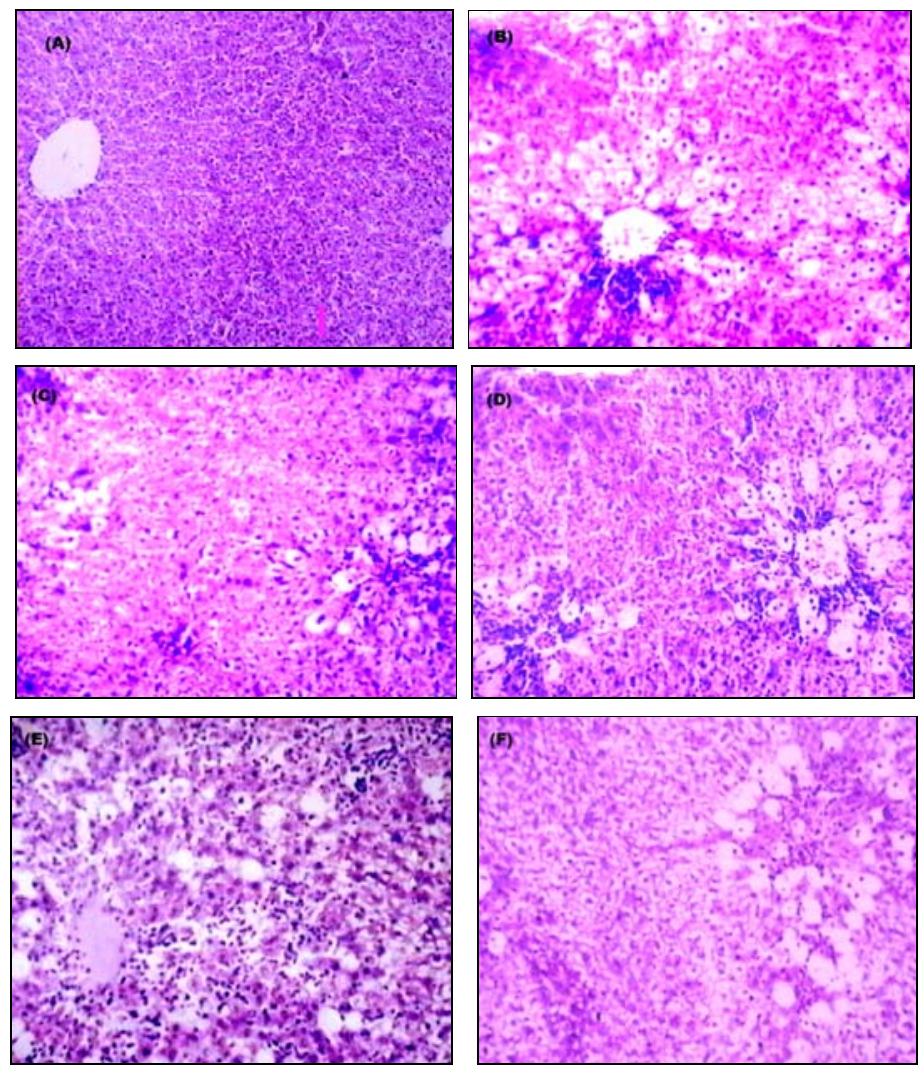

Fig.ure 1: A: Liver of rat in control group showing the normal histological structure of the hepatocytes in the hepatic cords with central veins, B. Liver of rat administrated carbon tetrachloride $\left(\mathrm{CCl}_{4}\right)$ only showing severe degenerated and necrobiotic changes (Centrolobular) in the hepatocytes with mononuclear leucocytic inflammatory cells surrounding the central vein as well as in focal manner between the hepatocytes, C: Liver of rat administrated $\mathrm{CCl}_{4}$ and protected by Plantago major showing moderate degenerated and necrobiotic changes (Centrolobular) in the hepatocytes with mononuclear leucocytic inflammatory cells infiltration inbetween and D: Liver of rat administrated $\mathrm{CCl}_{4}$ and protected by methanol extract of Diplotaxis acris showing few degenerated and necrobiotic changes in the Centro lobular area of the hepatic lobules E. Liver of rat administrated $\mathrm{CCl}_{4}$ and protected by Schouwia thebaica and F. Liver of rat administrated $\mathrm{CCl}_{4}$ and protected by silymarin. ( $\mathrm{H} \& \mathrm{E}$ X 40)

Carbon tetrachloride-treated rats exhibited a significant decrease in concentrations of serum glucose, triglycerides and cholesterol compared to normal control group. This is probably due to the accumulation of triglyceride in the hepatic cells. A block of the secretion of hepatic triglycerides into plasma is basic mechanism underlining the fatty liver induced in rat by $\mathrm{CCl}_{4}(\mathrm{Lombardi}$, 1966). Biochemical mechanism for $\mathrm{CCl}_{4}$ toxicity based on mitochondrial damage leads to accumulation of fat within 60 minutes and death of the hepatocytes, damage of endoplasmic reticulum within 30 minutes (Christie and Judah, 1954) and damage of lysosomes (Judah, 1969). 
Afr. J. Trad. CAM (2006) 3 (3): 1 - 9

The protective effect of plant extracts against $\mathrm{CCl}_{4}$ may be attributed to the presence of flavonoids, tannins, (Gilani and Janbaz, 1995), triterpenoids and steroids among the plant constituents that possess hepatoprotective effect (Gupta, et al., 2004). Flavonoids are known to be antioxidants, free radical scavengers and antilipoperoxidants leading to hepatoprotection (Al-Qarawi, et al., 2004). The active compounds of Plantago major seeds and Diplotaxis acris for the observed effects have not been identified in the present study. Many compounds known to be beneficial against carbon tetrachloride-mediated liver injury exert their protective action by toxin-mediated lipid peroxidation either via decreased production of carbon tetrachloride derived free radicals or through the antioxidant activity of the protective agents themselves (Gilani and Janbaz, 1995). Further investigation is required to identify the constituents of the tested plants responsible for the hepatoprotective effect.

\section{Acknowledgement:}

This work was financially supported by Cairo University, grant No. 1730/2003

\section{References}

1. Abell, L.L., Levy, B.B., Brodie, B. B. and Kendall, F.E. (1952). A simplified method for the estimation of total cholesterol in serum and demonstration of its specificity. J. Biol. Chem., 195: 357-366.

2. Al-Qarawi, A.A., Mousa, H.M, Ali, B.H., Abdel-Rahman, H. and El-Mougy, S.A. (2004). Protective effect of extracts from dates (Phoenix dactylifera L.) on carbon tetrachloride-induced hepatotoxicity in rats. Intern. J. Appl. Res. Vet. Med., 2(3): 176-180.

3. Alvarez, A., Pomar, F., Sevilla, M.A. and Monter, M.J., (1999). Gastrin antisecretory and antiulcer activities of an ethanolic extract of Bidens pilosa L. var. radiate Schult, Bip. J. Ethnopharmacol., 67: 333-340.

4. Atta, A.H. and Abo El-sooud, K., (2004). The antinociceptive effect of some Egyptian medicinal plant extracts. J. Ethnopharmacol., 95: 235-238.

5. Atta, A.H. and Mouneir, Samar, M., (2005). Evaluation of some medicinal plants extracts for antidiarrhoeal activity. Phytotherapy Research, 19(6): 481485.

6. Atta, A.H., Nasr, Soad, M. and Mouneir, Samar, M., (2005). Antiulcerogenic effect of some plant extracts. Nat. Prod. Rad. 4 (4): 258263.

7. Bustos, D.A. Tapia A.A Fersein. G.E. and Espinar L.A., (1996). Ethnopharmacobotanical survey of Bauchzeta district, San juan province, Aregentina Fitoterapia, 5: 411- 415.

8. Chiang, L.C., Ng, L.T., Chiang, W., Chang, M.Y. and Lin, C.C. (2003) Immunomodulatory activities of flavonoids, monoterpenoids, triterpenoids, iridoid glycosides and phenolic compounds of Plantago species. Planta Med. 69(7): 600-4.

9. Christie, G.S. and Judah, J.D., (1954). Mechanism of action of carbon tetrachloride on liver cells. Proc. Roy. Soc. Ser. B., 142: 241-257. 
10. Doumas, B.T., Watson, W.A., and Biggs, H.G. (1971): “Albumin standards and the measurement of serum albumin with bromocresol green.” Clin. Chim. Acta, 31: $87-96$.

11. Gilani, A.H. and Janbaz, K.H.,(1995). Preventive and curative effects of Artemisia absinthium on acetaminophen and $\mathrm{CCl}_{4}$-induced hepatotoxicity. Gen. Pharmacol., 26: 309-315.

12. Guillen, M.E.N., Emim J.A.S Souccar, C. and Lapa A.J., (1997). Analgesic and antiinflammatroy activities of the aqueous extract of Plantago major L. Intern. J. Pharmacognosy, 35: 99-104

13. Gurib- Fakim. A Sewrey, M., Gueho. J. and Dulloo. E., (1993). Medical ethnobotany of some weeds of Mauritius and Rodrigues. J. Ethnopharmacol., 39: 175-185

14. Harris, H.F. (1898). Cited by Carleton et al. (1967). “Carleton’s Histological Technique.” $4^{\text {th }}$ Ed. Oxford Univ. Press, New York, Torento.

15. Henary, R.J., Cannon, D.C. and Winkleman, J.W. (1974). "Clinical Chemistry Principles and Techniques.” $2^{\text {nd }}$ Ed. Harper and Roe, New York.

16. Jain. S.K. (1991). Dictionary of Indian folk Medicine and Ethnobotany, Deep Publications, New Delhi, P. 145

17. Joshi D.N., Sah, B.C.L., and Suri, R.K. (1982). Some medicinal plants of Rudranath Bugyal (dist. Chamoli) U.P. Bull. Medicoethnobotanical Res. 3: 27-43.

18. Judah, J.D. (1969). “Biochemical disturbances in liver injury”. British Med. Bull., 25(3): 274-277.

19. Lombardi, B. (1966). "Considerations on pathogenesis of fatty liver". Lab. Invest., 15: 1-20.

20. Malaya, G. Mazumder, U.K., Kumar, T.S., Gromathi, P. and Kumar, R.S. (2004). Antioxidant and hepatoprotective effect of Bauhinia racemosa against paracetamol and carbon tetrachloride induced liver damage in rats. Iranian Journal of Pharmacology and Therapeutics 3: 12-20.

21. Malloy, H.T. and Evelyn, K.A. (1937). The determination of bilirubin with the photoelectric colorimeter. J. Biol. Chem., 119: 481-490.

22. Recknagel, R.O., Glende, E.A.; JrDolak, J.A. and Walter, R.L., (1989). Mechanism of carbon tetrachloride toxicity. Pharmacol. Ther., 43: 139-154.

23. Reitman, S.M.D. and Frankel, S. (1957). A colorimeter method for determination of serum glutamic oxaloacetic acid and glutamic pyruvic acid transferases. Am. J. Clin. Pathol., 28: 56 - 63.

24. Ruiz, A.R., De la Tprre , R.A., Alonso,N., villaescusa. A., Betancourt, J. and Vizoso. A., (1996). Screening of medicinal plant for induction of somatic segration activity in Aspergillus nidulans. J. Ethnopharmacol., 52: $123-127$

25. Samuelsen, A.B. (2000). The traditional uses, chemical constituents and biological activities of Plantago major L. A Review. J. Ethnopharmacol., (1998), 61(10): 1212-5.

26. Spring, M.A. (1989) Ethnopharmacologic analysis of medicinal plants used by Loation Hmong refugees in Minnesota. J. Ethnopharmacol. 26 : 65-91. 
Afr. J. Trad. CAM (2006) 3 (3): 1 - 9

27. Stahl, E. (1969). Thin Layer Chromatography. 2nd edition, Springer-Verlag, Berlin, Heidelberg, New York.

28. Szasz, G. (1969).“A kinetic photometric method for serum gamma glutamyl transferase.” Clin. Chem., 15: 124-136.

29. Tanira, M.O.M., Shah, A.H., Mohsin, A., Ageel, A.M. and Qureshi, S., (1996). Pharmacological and toxicological investigations on Foeniculum vulgare dried fruit extract in experimental animals. Phytother. Res. 10: $33-$ 36.

30. Trinder, P. (1969). Enzymatic methods for glucose determination. Ann. Clin. Biochem., 6: 24-26.

31. Zagari, A. (1992). Medicinal plants. Iran Book, Tehran. P.969 Tehran University Publications No 1819/4

32. VanHendle, E. and Zilversmith, D.B. (1957). Determination of serum triglycerides. J. Lab. Clin. Med., 50: 152.

33. Venukumar, M.R. and Latha, M.S. (2002). Hepatoprotective effect of metabolic extract of Cuculigo orchioides in $\mathrm{CCl}_{4}$-treated male rats. Indian J. Pharmacol. 34: 269-275.

34. Wagner, H., Bladt, S. and Zgainski, E.M. (1983). Drogen Analyse, Springerverlag, Berlin, Heidelberg, New York.

35. Wei, Y.H. (1998). Oxidative stress and mitochondrial DNA mutations in human aging. Proc Soc Exp. Boil. Med., 217: 53-63. 